\title{
Histopathological and ultrastructural studies of the tapeworm Monobothrium wageneri (Caryophyllidea) in the intestinal tract of tench Tinca tinca
}

\author{
C. F. Williams ${ }^{1, *}$, L. G. Poddubnaya ${ }^{2}$, T. Scholz ${ }^{3}$, J. F. Turnbull ${ }^{4}$, H. W. Ferguson ${ }^{5}$ \\ ${ }^{1}$ Environment Agency, Bromholme Lane, Brampton, Cambridgeshire, PE28 4NE, UK \\ ${ }^{2}$ Institute of Biology for Inland Waters, Russian Academy of Sciences, 152742, Borok, Yaroslavl Province, Russia \\ ${ }^{3}$ Institute of Parasitology, Biology Centre of the Academy of Sciences of the Czech Republic, Branišovská 31 , \\ 37005 České Budějovice, Czech Republic \\ ${ }^{4}$ Institute of Aquaculture, University of Stirling, Stirling, FK9 4LA, UK \\ ${ }^{5}$ Department of Pathology, School of Veterinary Medicine, St George's University, Grenada, West Indies
}

\begin{abstract}
Monobothrium wageneri is a monozoic caryophyllidean tapeworm of tench Tinca tinca. The pathological changes caused by this parasite within the intestinal tract of wild tench are described for the first time. Parasites were found attached to the anterior third of the intestine in tight clusters comprising up to 109 tapeworms. Infection was associated with the formation of raised inflammatory swellings surrounding the parasites. This host response, combined with the deep penetration of the scolex into the gut wall, formed a very firm seat of parasite attachment. Histopathological changes were characterised by a pronounced fibrogranulomatous lesion that extended through all layers of the intestine. This was accompanied by haemorrhage, oedema, necrosis and degeneration of the muscularis. A marked eosinophilic interface layer between the scolex of the tapeworm and gut wall indicated intimate host-parasite contact. Ultrastructural examinations revealed coniform spinitriches covering the neck and lateral sides of the scolex and capilliform filitriches present on the apical end of the scolex. Numerous glandular cytons (tegumental glands) were recorded throughout the scolex tegument. Large numbers of secretory granules discharged from the glands through a network of processes onto the scolex surface were consistent with distancing the cellular responses of the host. Observations of severe inflammatory lesions, partial intestinal occlusion and the potential for intestinal perforation represent important pathological changes that are consistent with loss of normal gut function. The lesions associated with the attachment of $M$. wageneri are more severe than those recorded for any other tapeworm of British freshwater fish.
\end{abstract}

KEY WORDS: Monobothrium wageneri $\cdot$ Pathology $\cdot$ Tapeworm $\cdot$ Tench $\cdot$ Fisheries

\section{INTRODUCTION}

Monobothrium wageneri Nybelin, 1922 is a monozoic caryophyllidean tapeworm of tench Tinca tinca L. The parasite was first described (as Caryophyllaeus tuba) from wild tench in northern Italy (see
Nybelin 1922). Established populations have since been recorded from Poland (Janiszewska 1954), former Czechoslovakia (Scholz 1987), former USSR (Protasova et al. 1990), England (Gibson 1993), and Germany (Sures et al. 1997). M. wageneri is one of a number of tapeworms introduced to the UK with the 
international trade in cyprinid fish (Gibson 1993). Other recent examples include Atractolytocestus huronensis Anthony, 1958, Khawia sinensis Hsü, 1935 (Caryophyllidea) and Bothriocephalus acheilognathi Yamaguti, 1934 (Bothriocephalidea), all of which have received considerable attention as potential pathogens of common carp Cyprinus carpio L. (Andrews et al. 1981, Hoole \& Nissan 1994, Morley \& Hoole 1995, Hoole et al. 2001, Majoros et al. 2003, Molnár et al. 2003, Oros et al. 2009). By contrast, literature on $M$. wageneri is sparse and confined largely to morphological descriptions (Kozicka 1959, Dubinina 1987, Scholz 1987, Protasova et al. 1990, Scholz et al. 1992). These reports shed limited light onto our understanding of the pathological importance of this parasite to infected tench.

The genus Monobothrium Diesing, 1863 comprises 7 species, which may be divided into 2 morphologically and geographically distinct groups (Mackiewicz 1972). M. hunteri Mackiewicz, 1963, M. ulmeri Calentine and Mackiewicz, 1966, M. ingens Hunter, 1927, M. fossae Williams, 1974, and M. mackiewiczi Williams, 1974, all infect North American catostomid fishes (Mackiewicz 1963, Williams 1974, Hoffman 1999). M. wageneri and M. auriculatum Kulakovskaya, 1961 are the only European representatives of this genus, the latter species having been documented on only one occasion from Ukraine (Kulakovskaya 1961).

Previous studies state that North American species of Monobothrium may be pathogenic due to the severe lesions that result from their attachment (Mackiewicz 1972, Mackiewicz et al. 1972, Hayunga, 1979a). Observations by Janiszewska (1954) suggest this may also be true for $M$. wageneri. Conversely, during a review of parasite introductions to British freshwater fish, Kennedy (1994) described M. wageneri as non-pathogenic and of lesser pathological importance than Khawia sinensis and Bothriocephalus acheilognathi. It was not clear how such comparisons were made, as, until now, the pathology caused by $M$. wageneri has not been described. This represents an important area of study in view of the dangers posed by non-native parasite introductions (Kennedy 1994, Kirk 2003, Gozlan et al. 2005) and the importance of tench to freshwater fisheries in the British Isles (Environment Agency 2004).

The present study describes the histopathological changes caused by Monobothrium wageneri within the intestinal tract of tench. The ultrastructure of the host-parasite interface is also examined to establish the relationship between tapeworm attachment and the host responses to infection.

\section{MATERIALS AND METHODS}

\section{Fish sampling and examination}

Records of Monobothrium wageneri from freshwater fisheries in England and Wales were collated from a database of fish-health records held by the Environment Agency, Brampton, England. Material for examination comprised of formalin-fixed, archived tissues collected during historic parasitological examinations by the senior author (C.F.W.). This material was supported by an additional sample of 20 tench, obtained from an infected stillwater fishery in the Midlands region of England. Fish were captured by seine-netting and transported live to holding facilities at the Environment Agency.

Tench were killed by anaesthetic overdose using benzocaine solution. Each fish was measured, weighed, and examined grossly for the presence of external abnormalities. The intestinal tract was removed in its entirety, opened and examined under a dissecting microscope for parasites. A small number of tapeworms were removed from the gut, fixed in cold $10 \%$ buffered formalin, stained in paracarmine, and examined microscopically to confirm identification. Voucher specimens of Monobothrium wageneri were deposited in the Natural History Museum, London (accession number 2009.11.13.1-3).

\section{Histopathology and electron microscopy}

Regions of infected intestine were fixed in $10 \%$ neutral buffered formalin (NBF), trimmed, dehydrated in alcohol series, cleared and embedded in paraffin wax. Sections $(5 \mu \mathrm{m})$ were dried at $50^{\circ} \mathrm{C}$, stained using Mayer's haematoxylin and eosin and examined microscopically for pathological changes.

Tissues for scanning electron microscopy were fixed in $10 \% \mathrm{NBF}$, dehydrated in a graded alcohol series, critically point dried in $\mathrm{CO}_{2}$, sputter-coated with gold and viewed with a JEOL-7401F scanning electron microscope operating at $15 \mathrm{kV}$. Tissues for transmission electron microscopy were fixed overnight at $4{ }^{\circ} \mathrm{C}$ using $2 \%$ glutaraldehyde in $0.1 \mathrm{M}$ phosphate buffer $(\mathrm{pH}=7.2)$. Trimmed samples were postfixed for $1 \mathrm{~h}$ in $1 \%$ osmium tetroxide and then routinely processed into Spurr's resin. Sections were mounted on uncoated grids and stained with uranyl acetate and lead citrate and examined using a JEOL1010 transmission electron microscope operating at $80 \mathrm{kV}$. 


\section{RESULTS}

\section{Distribution and infection characteristics}

Monobothrium wageneri has been recorded from 15 stillwater fisheries in England and Wales. These sites are located primarily in the south east and Midland regions of England (Fig. 1). The parasite has not been recorded from the southwest, northeast, or northwest regions of England, and only once from north Wales. M. wageneri has not been recorded from Scotland or Northern Ireland (A. Shinn \& D. Evans pers. comm.).

A total of $8(40 \%)$ of the 20 tench examined during the study were infected with Monobothrium wageneri. The intensity of infection ranged from 1 to 15 tapeworms per host (mean 4.1 parasites). Infected tench harboured both adult and juvenile tapeworms. Archived tissues from an additional 11 infected tench included fixed regions of the intestine from 2 heavily infected fish, each harbouring in excess of 100 tapeworms.

\section{General attachment characteristics of Monobothrium wageneri}

Monobothrium wageneri were attached primarily within the anterior third of the intestine, usually in, or in very close proximity to, the first intestinal bend. Attachment involved penetration of the parasite's blunt, rounded scolex (Fig. 2), deep into the intestine wall. Parasites were usually observed in tight clusters, consisting of between 3 and 109 tapeworms attached in discrete lesions (Figs. 3 \& 4). The heaviest infection observed during the study comprised of 117 tapeworms. This comprised 3 focal lesions within the anterior intestine consisting of 109, 5, and 3 tapeworms, respectively. These clusters contained worms measuring between 6 and $37 \mathrm{~mm}$ in length. Juvenile tapeworms, measuring as little as $3 \mathrm{~mm}$, were found in only small numbers and did not show obvious signs of clustering.

Attachment of Monobothrium wageneri resulted in the formation of a raised, rounded nodule surrounding the tapeworms (Fig. 3). Infections comprising as few as 4 tapeworms caused swellings that were visible from the outside of the intestine prior to dissection (Fig. 5). These gross pathological changes, combined with the relatively large size and white colour of adult tapeworms, enabled straightforward detection during post-mortem examination. Conversely, the absence of noticeable swellings, combined with

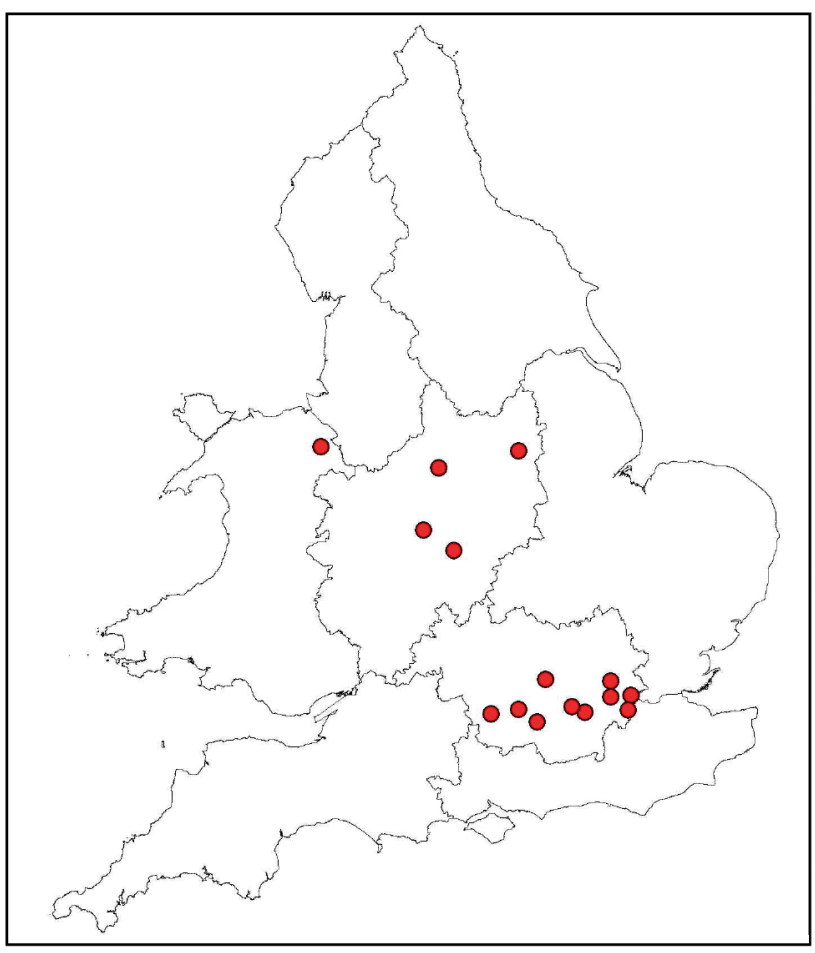

Fig. 1. Monobothrium wageneri infecting Tinca tinca. Records from freshwater fisheries in England and Wales (1992-2010)

the smaller size and translucency of juvenile parasites, made detection problematic. This was particularly notable in large fish where very small worms protruded only a short distance beyond the intestinal folds.

\section{Histopathological changes}

During attachment, the scolex of Monobothrium wageneri extended deep into the lamina propria as far as the muscularis (Fig. 6). This resulted in compression of the scolex against the intestinal musculature. The focal attachment of tapeworms, lateral expansion of their scoleces and formation of a protuberant nodule within the intestine provided parasites with a very firm seat of attachment (Fig. 7). This was often so firm that dissection of the intestinal tract was necessary to remove individuals without damage.

Infections of adult Monobothrium wageneri invoked a pronounced, progressive fibrogranulomatous response that extended throughout all layers of the intestine (Fig. 6). This chronic host reaction was associated with a complete loss of normal gut architecture and replacement of the mucosa, lamina propria and muscularis with inflammatory tissue. These 

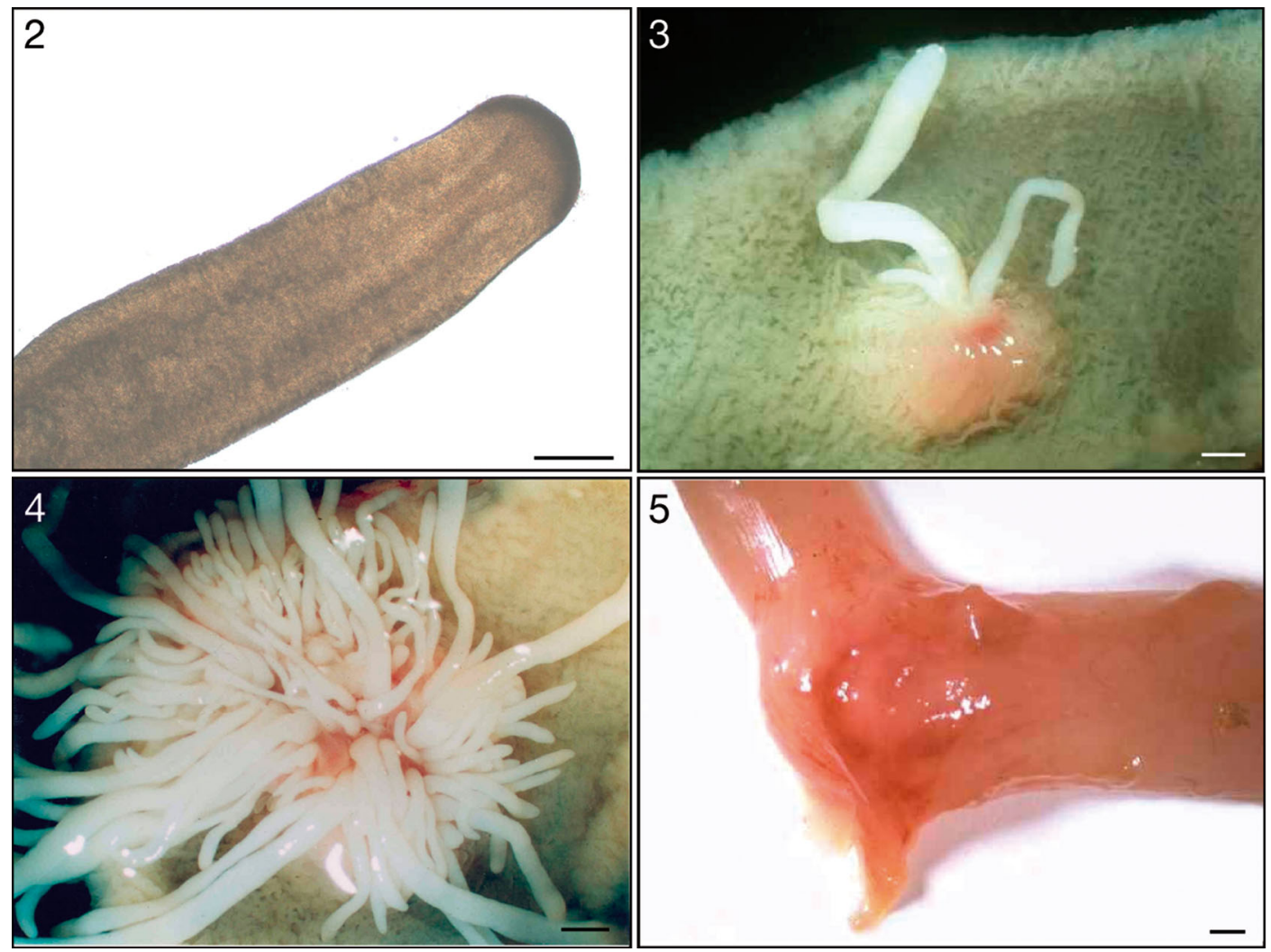

Figs. 2 to 5. Monobothrium wageneri infecting Tinca tinca. Fig. 2. Anterior region showing its blunt, rounded scolex (scale bar $=0.5 \mathrm{~mm}$ ). Fig. 3. Three tapeworms attached to the intestinal wall of tench, showing characteristic clustered attachment and resultant inflammatory nodule (scale bar $=1 \mathrm{~mm}$ ). Fig. 4. Heavy infection comprising 109 tapeworms in a single cluster (scale bar $=1 \mathrm{~mm}$ ). Fig. 5. Anterior intestine of tench. Focal attachment of 6 tapeworms at the first intestinal bend has caused pronounced swelling of the intestine at this point (scale bar $=1 \mathrm{~mm}$ )

changes were consistent for both light and heavy parasite burdens, with as few as 3 tapeworms causing full thickness enteritis, extending onto the serosal surface. The combination of tapeworms within the gut lumen and pronounced inflammatory swellings led to partial occlusion of the intestinal tract, even during light parasite infection (Fig. 8). This was most pronounced when tapeworms were attached at the first intestinal bend.

The inflammatory swellings surrounding Monobothrium wageneri comprised mainly fibroblasts, but also included lymphocytes, plasma cells, macrophages, and large numbers of eosinophilic granular cells. These severe fibrogranulomatous reactions were evident in stained sections as a pale eosinophilic halo surrounding the clustered scoleces (Fig. 6). During most infections, significant lymphoid or lympho-plasmacytic responses were observed. However, these were confined largely to regions beyond the halo of fibroblastic tissue (Fig. 9). Activation of the mesothelium on the peritoneal side of the intestine was frequently noted, with hypertrophy and hyperplasia of mesothelial cells. Haemorrhage, oedema and degeneration of the muscularis accompanied the heaviest parasite infections. In these cases, pathological changes to the muscle layers extended far beyond the immediate point of parasite penetration. Two lesions comprising 109 and 4 parasites, respectively, had pathological changes consistent with early stages of intestinal perforation.

The presence of a marked eosinophilic layer around the anterior most region of the scolex indicated intimate host-parasite contact (Fig. 10). However, reduced numbers of inflammatory cells were recorded in this region, with only occasional eosinophilic granular cells and red blood cells interspersed within the fibroblastic tissue (Fig. 11).

The pathological changes caused by juvenile Monobothrium wageneri differed to those associated with established adult tapeworms. Such infections were characterised by a loss of epithelium adjacent to the scolex and neck of the parasite, but less severe 

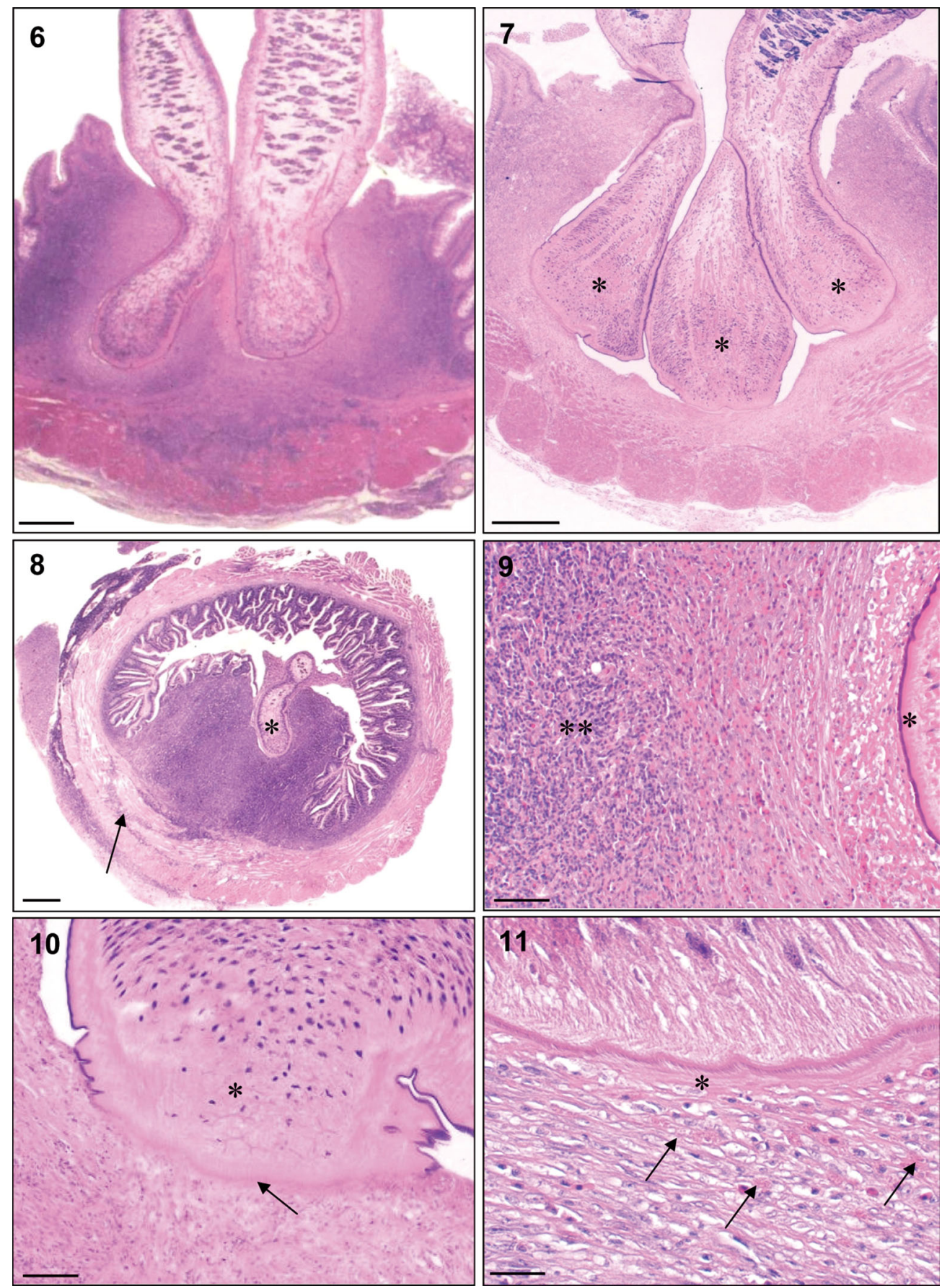

Figs. 6 to 11. Monobothrium wageneri infecting Tinca tinca. Fig. 6. Transverse section through tench intestine infected by 2 tapeworms showing pronounced inflammatory response throughout all layers of the intestine (scale bar $=0.5 \mathrm{~mm})$. Fig. 7 . Focal attachment of 3 tapeworms penetrating intestine of tench as far as the muscularis. Lateral expansion of the scoleces (*) anchors the tapeworms firmly within the surrounding inflammatory nodule (scale bar $=0.5 \mathrm{~mm}$ ). Fig. 8. Transverse section through inflammatory lesion comprising 4 tapeworms ( $*$, one seen in section). Severe pathological changes extend through the muscularis (arrow), with marked lympho-plasmacytic inflammatory response reducing the gut lumen (scale bar $=0.5 \mathrm{~mm}$ ). Fig. 9 . Transverse section through intestinal nodule of tench. An eosinophilic layer, consisting of fibroblasts and eosinophilic granular cells surrounds the tapeworm (*), beyond which a pronounced lymphoid response can be seen throughout the lamina propria $(* *)($ scale bar $=40 \mu \mathrm{m})$. Fig. 10. Attachment of tapeworm $(*)$ showing intimate host-parasite contact, characterised by prominent eosinophilic interface layer (arrow) (scale bar $=80 \mu \mathrm{m}$ ). Fig. 11. Fibroblastic tissue adjacent to the host-parasite interface (*) with reduced numbers of inflammatory cells. Small numbers of eosinophilic granular cells (arrows) and red blood cells were recorded in this region (scale bar $=20 \mu \mathrm{m}$ ) 

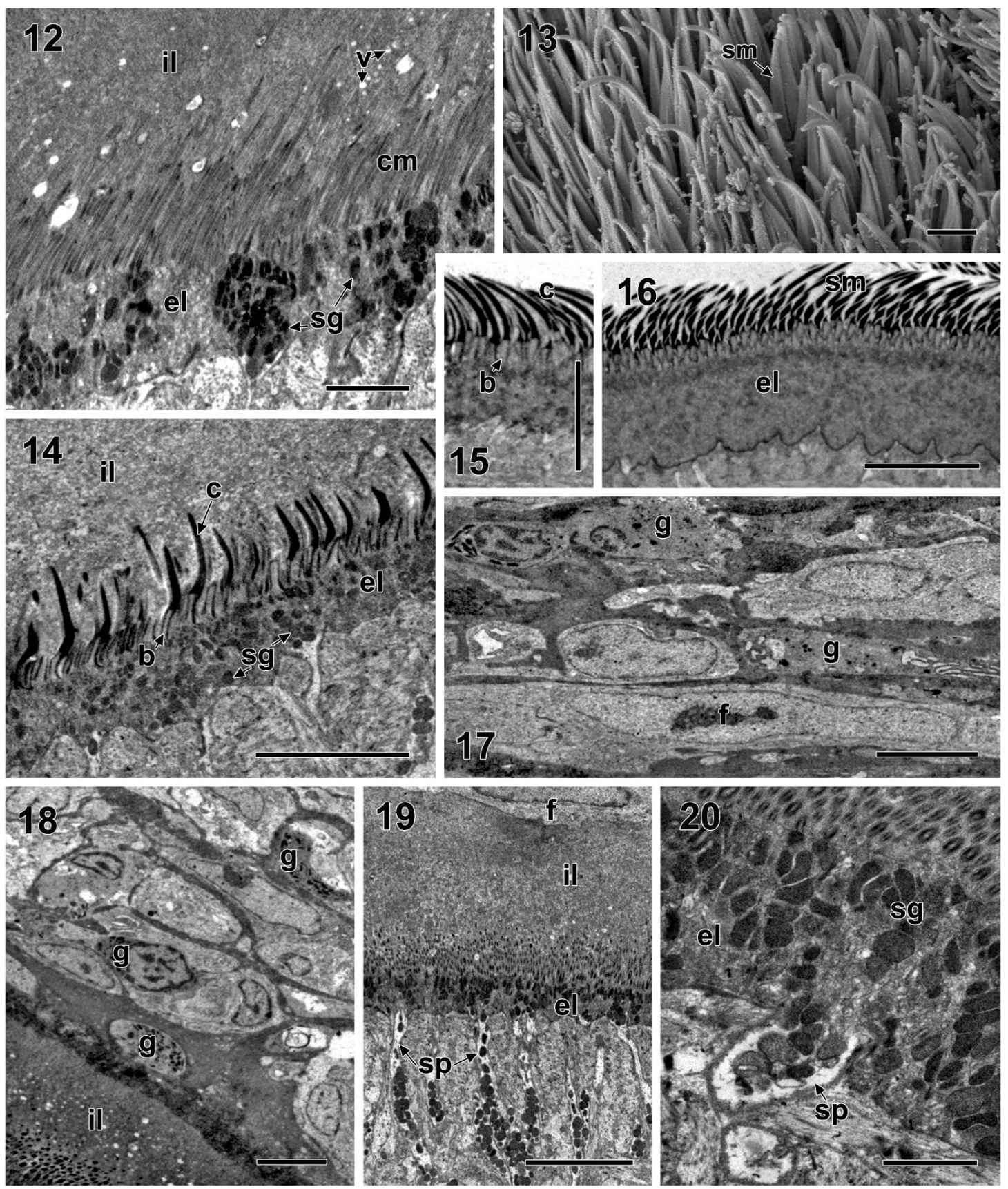

Figs. 12 to 20. Monobothrium wageneri infecting Tinca tinca. Fig. 12. Ultrastructural view of anterior end of the tapeworm scolex showing cytoplasm of epithelial layer with electron-dense granules and electron-lucent vesicles. Capilliform microtriches covering the scolex surface are embedded into a thick granular interface layer (scale bar $=2 \mu \mathrm{m}$ ). Fig. 13. Scanning electron micrograph of coniform spinitriches covering the surface of the neck region of $M$. wageneri (scale bar $=1 \mu \mathrm{m})$. Fig. 14 . Lateral scolex region. Note the epithelial cytoplasm filled with electron-dense secretory granules and surface covered in shorter spinitriches embedded in the granular interface layer (scale bar $=5 \mu \mathrm{m}$ ). Fig. 15. Ultrastructure of spinitriches covering neck region (scale bar $=5 \mu \mathrm{m}$ ). Fig. 16. Epithelial layer of neck region covered with spinitriches (scale bar $=5 \mu \mathrm{m}$ ). Fig. 17. Granulocytes and fibroblast localized outside the granular interface layer surrounded the scolex region (scale bar $=5 \mu \mathrm{m}$ ). Fig. 18. Region adjacent to host parasite interface, showing a number of granulocytes (scale bar $=5 \mu \mathrm{m}$ ). Fig. 19. Anterior scolex region, showing electrondense secretory granules within outer epithelial cytoplasm and numerous granular processes originating from tegumental glands. Note homogeneous thick granular interface layer, with fibroblasts outside this layer (scale bar $=5 \mu \mathrm{m}$ ). Fig. 20 . Epithelial cytoplasm of anterior scolex filled with electron-lucent vesicles and electron-dense secretory granules of tegumental glands (scale bar $=1 \mu \mathrm{m})$. b: microthrix base; $\mathrm{c}$ : microthrix cap; $\mathrm{cm}$ : capilliform filitriches; el: epithelial layer; f: fibroblast; g: granulocytes; il: interface layer; sg: secretory granules; sm: coniform spinitriches (= spiniform microtriches); sp: secretory processes; v: vesicles 
inflammatory responses. Focal haemorrhage and necrosis of cells within the lamina propria were recorded around the scoleces of these juvenile tapeworms. The attachment of juvenile $M$. wageneri did not result in raised intestinal swellings.

\section{Ultrastructural observations of Monobothrium wageneri}

There were regional differences in the forms of microtriches covering the tegument of the scolexneck region of adult Monobothrium wageneri. Differences were also recorded in the content of cytoplasmic inclusions within the distal tegumental layer of this body region (Figs. 12 to 16).

The neck of Monobothrium wageneri was covered with coniform spinitriches (see Chervy 2009 for unified terminology of cestode microtriches). These possessed a well-defined, tapered, electron-dense distal cap that pointed posteriorly and measured approximately $3 \mu \mathrm{m}$ in length. The short cylindrical base of these microtriches measured approximately $0.8 \mu \mathrm{m}$ in length and $0.4 \mu \mathrm{m}$ in diameter (Figs. 13, 15, 16).

The outer epithelial layer of the neck region of Monobothrium wageneri included numerous inclusions with electron-dense bodies and vesicles. The outer epithelium of the scolex region contained large numbers of vesicles and electron-dense secretory granules (Figs. 12, 14, 20). The surface of the lateral portion of the scolex was also covered with coniform spinitriches that had a shorter distal cap (about $2 \mu \mathrm{m}$ long) and longer base (about $1 \mu \mathrm{m}$ ). Between these, individual capilliform filitriches were observed (Fig. 14). The anterior scolex region was only covered with capilliform filitriches that possessed a long, thin base measuring approximately $2 \mu \mathrm{m}$ in length and $0.07 \mu \mathrm{m}$ in diameter, and a thin cap measuring approximately $1 \mu \mathrm{m}$ in length (Fig. 12). Surface structures of the scolex region were embedded into a thick granular interface layer (Figs. 12, 14, 19). Vesicles of different sizes were also observed within this layer (Fig. 12), beyond which an array of host cells was observed, some of which were granulocytes, but most had the appearance of fibroblasts (Figs. 17 to 19).

The tegumental layer of the anterior and lateral parts of the scolex of Monobothrium wageneri contained a network of processes filled with electrondense secretory granules of varying shapes (Fig. 19). These secretions originated from glandular cell bodies, the processes of which were connected with the outer epithelium by cytoplasmic bridges, allowing the release of secretory granules into the epithelial layer (Figs. 12, 14, 19, 20). These secretions were discharged onto the body surface as separate granules and were consistent with a merocrine mechanism (Fig. 20). The discharge of these granules onto the anterior and lateral scolex regions of $M$. wageneri resulted in the formation of a homogeneous, finely granular interface layer between host and parasite, measuring approximately $8 \mu \mathrm{m}$ in thickness (Figs. 12, $14,18,19)$.

\section{DISCUSSION}

The attachment of Monobothrium wageneri within the intestinal tract of tench was associated with pronounced pathological changes. Lesions were characterised by a chronic, active fibrogranulomatous enteritis, with progressive loss of mucosa, lamina propria, and muscularis. These are significant changes that suggest reduction of normal gut function within affected regions.

These observations share similarities with some tapeworms of North American catostomid fishes. According to Mackiewicz et al. (1972), Monobothrium ingens, M. ulmeri, Hunterella nodulosa Mackiewicz and McCrae, 1967 and Biacetabulum biloculoides Mackiewicz and McCrae, 1965 tapeworms of freshwater suckers are pathogenic, due to the severity of inflammatory reactions caused by their infections and the resultant intestinal disturbance. Other workers have supported the pathological importance of North American species of Monobothrium, highlighting the need to elucidate the scolex characteristics of these tapeworms (Hayunga 1979b). This paper is the first to describe the ultrastructural characteristics of $M$. wageneri and the pathological changes associated with this tapeworm within the intestines of tench.

The pathological changes associated with Monobothrium wageneri differ markedly from those caused by other intestinal tapeworms of European freshwater fish. These differences include the magnitude of the inflammatory response, the involvement of all layers of the intestine, and complete loss of gut architecture, even during light tapeworm burdens. It is proposed that these changes stem from a combination of factors, namely scolex morphology, depth of parasite penetration, focal attachment to the gut wall, and secretions from the tegumental glands. Although these factors are inextricably linked, the importance of each will be discussed briefly in turn. 


\section{Scolex morphology}

According to Mackiewicz et al. (1972), the severity of pathology caused by caryophyllidean cestodes is inversely proportional to the degree of scolex specialisation. Hamada \& El-Naggar (2003) support this generalisation, highlighting that even subtle characteristics of scolex morphology of Monobothrioides chalmersius (Woodland, 1924) can influence tapeworm attachment and resultant pathological changes in Clarius gariepinus. Ibraheem \& Mackiewicz (2006) described the scolex morphology, attachment characteristics and lesions associated with Wenyonia virilis Woodland, 1923 in Synodontis schall (Bloch et Schneider). These studies revealed how minute longitudinal ridges on the scolex of this parasite were an important influence on attachment behaviour and pathological changes within infected fish.

Monobothrium wageneri possesses a blunt, truncated scolex with shallow longitudinal grooves (Mackiewicz 1963, Scholz 1987). This lack of scolex specialisation (i.e. absence of hooks, suckers and bothridia) may, in part, explain the severity of lesions associated with tapeworms of this genus. However, this relationship does not apply to all species. Caryophyllaeides fennica (Schneider, 1902), a common tapeworm of bream Abramis brama and other cyprinid fish, also possesses a blunt, rounded scolex (Chubb et al. 1987) but attaches superficially to the gut wall, causing only localised mechanical damage and mild inflammatory responses (C. F. Williams pers. obs.). This suggests that the depth of scolex penetration, in addition to scolex morphology, is an important influence on the severity of pathological changes (Williams \& Jones 1994).

\section{Depth of penetration}

Molnár (2005) emphasised the importance of depth of scolex penetration whilst describing the intestinal pathology of gryporhynchid cestodes in gibel carp Carassius gibelio (Bloch). Molnár (2005) compared the lesions associated with both larval and adult cestodes and concluded that most damage was caused by parasites with deeply embedded scoleces. During attachment, Monobothrium wageneri inserts its scolex deep into the intestine of tench as far as the muscularis. This may in part explain the severity of inflammatory changes observed within the intestine of tench (Williams \& Jones 1994). These responses may further benefit tapeworm attachment, engulfing the anterior region of the parasite in the absence of specialised scolex characteristics (Chakravarty \& Tandon 1989).

The attachment behaviour of Monobothrium wageneri differs from that of all other cestodes recorded from European freshwater fish. In contrast, Khawia sinensis and Caryophyllaeus laticeps use their fanshaped scoleces to engulf the intestinal folds, leading to relatively superficial alterations (Karanis \& Taraschewski 1993, Morley \& Hoole 1995, Hoole et al. 2001). Attachment of 2 bothriocephalidean cestodes possessing paired bothria, Eubothrium crassum and Bothriocephalus acheilognathi, can be more forceful, but rarely breaches the epithelium (Hoole \& Nisan 1994, Bosi et al. 2005). Deeper attachment behaviour is shown by Atractolytocestus huronensis, which inserts its highly mobile, arrow-shaped scolex into the intestinal crypts of common carp. This tapeworm causes mechanical disruption to the epithelium and stimulates cellular infiltrations that extend into the lamina propria (Molnár et al. 2003). Attachment of Cyathocephalus truncatus in brown trout Salmo trutta L. involves deep penetration of its funnel-like scolex, which anchors the parasite very firmly to the mucosa. However, the pathological changes associated with $M$. wageneri far exceed these other species. This may be explained by the more invasive attachment behaviour of this parasite and the focal attachment of tapeworms within the intestinal tract.

\section{Focal attachment}

Most intestinal tapeworms attach in favoured regions of the intestine, but only a few species exhibit tight clustering behaviour (Mackiewicz \& McCrae 1962, Mackiewicz 1963, 1968, Mackiewicz et al. 1972). Focal attachment has been linked with other nodule-forming tapeworms (Mackiewicz \& McCrae 1962), but it is not consistent with all (Chakravarty \& Tandon 1989). The mechanisms influencing clustered parasite attachment are believed to include host-derived cues, nutritional gradients within the gut, and chemical signalling by conspecific parasites or subsequent gut lesions. It has been suggested that this behaviour may benefit tapeworm reproduction, penetration of the intestine and nutrition (Kennedy 1983, L. F. Khalil pers. comm.).

Although the focal attachment of Monobothrium wageneri limits the area of gut damaged by the parasite, the tight clustering of tapeworms accentuates the severity of individual lesions. Pronounced inflammatory nodules, leading to partial occlusion of the intestinal tract were recorded with infections com- 
prising as few as 3 adult tapeworms. Heavier infections, comprising between 6 and 109 tapeworms, revealed changes consistent with early intestinal perforation. Intestinal occlusion and rupture are unusual and extreme consequences of tapeworm infection (Williams \& Jones 1994). These are among the most serious impacts caused by intestinal tapeworms, which have been associated with nutritional disturbance, debilitation and even death of heavily infected fish (Körting 1994, Hoole et al. 2001).

\section{Ultrastructure of Monobothrium wageneri}

Ultrastructural observations suggest that the microtriches covering the tegument of Monobothrium wageneri and secretions from the tegumental glands may have important influences on attachment behaviour, as well as the cellular responses of infected tench.

Two different types of microtriches were recorded covering the scolex and neck regions of adult Monobothrium wageneri. Coniform spinitriches with long distal caps were associated with the neck of the tapeworm. Coniform spinitriches, with shorter distal caps and longer bases, were also recorded along the lateral surfaces of the scolex. Capilliform filitriches were found covering the apical surface of the scolex. Such regional differences may be related to specific morphological adaptations of Monobothrium, where the anterior portion of the parasite is deeply embedded within intestinal nodules. The electron-dense, welldeveloped cap of spinitriches is thought to be involved in protection and anchoring of tapeworms within the intestine (Rothman 1963, Kuperman 1988, Jones 1998, Caira \& Littlewood 2001). The presence of spinitriches with well-developed distal caps covering the neck and lateral scolex of $M$. wageneri may therefore aid parasite attachment, enabling the interdigitation of microtriches of neighbouring tapeworms as well as with the host microvilli along the lateral walls of the intestine. Although filitriches are associated primarily with nutrition, the presence of thin, capilliform filitriches deeply embedded within the interface layer between the intestine and anterior extremity of the scolex suggests that these may also serve as root-like structures during attachment to the gut surface. These microtriches, combined with the observed scolex secretions, are likely to be responsible for the very firm attachment of the scolex to the intestine. Tearing of the tegument during removal of M. wageneri, with microtriches remaining lodged within this host-parasite interface, supports this assumption.
Tapeworms possess a range of different glands within their scolex, the secretions from which may have different roles and effects on the host (Hayunga 1979a,b, Richards \& Arme 1981, Kuperman \& Davydov 1982, Whittington \& Cribb 2001, Poddubnaya et al. 2007). Although the function of these glandular elements remain speculative (Whittington \& Cribb 2001), it has been suggested that these may have an adhesive role, and may aid penetration of the scolex into the gut, protect the parasite against host responses or mechanical abrasions, or promote the breakdown of nutritional products (Mackiewicz 1972, Hayunga 1979a,b, Sircar \& Sinha 1980, Kuperman \& Davydov 1982, Davydov \& Poddubnaya 1988, Garo 2000, Poddubnaya et al. 2007). Hayunga (1991) suggested that such secretions were responsible for the development of an adhesive interface between the scolex and intestine of caryophyllidean tapeworms.

The present study indicates that the secretions of the tegumental glands are consistent with the formation of the homogeneous, finely-granular interface matrix between the intestine of tench and the scolex of Monobothrium wageneri. This is supported by observations of glandular cytons within the tegument of the scolex, a fusion of secretory processes with the distal tegumental cytoplasm along the anterior and lateral scolex regions, an interfusion of secretory granules within the distal cytoplasm, and the active discharge of large numbers of finely glandular secretory granules directly onto the anterior and lateral scolex surfaces.

Hayunga (1979a) described electron-lucent secretions from the syncytial tegumental glands of Hunterella nodulosa, a caryophyllidean tapeworm that causes nodule formation within the intestine of the white sucker Catostomus commersoni Lacépède. Richards \& Arme (1981) detailed the scolex ultrastructure of C. laticeps, and highlighted greater lucency of the secretions originating from the syncytial tegumental glands of this parasite. These authors also highlighted the limited pathology caused by this tapeworm compared with other species of caryophyllideans. The glandular characteristics of other Monobothrium spp. have not been examined, making it difficult to assess the role of these secretions in the observed intestinal swellings. The absence of nodule formation during the attachment of $M$. hunteri studied by Mackiewicz (1963) suggests that this species may either possess different glandular elements, or exhibits alternative attachment behaviour.

It has been suggested that apocrine and/or microapocrine glands, responsible for the release of secre- 
tory products from adult Caryophyllidea, are modified tegumentary cells within the scolex (Hayunga 1979a,b, Richards \& Arme 1981, Davydov \& Poddubnaya 1988, Kuperman 1988). Histochemical and experimental examinations suggest that secretions from the tegumentary glands of caryophyllidean tapeworms consist of neutral glycoproteins that may assist in protecting the worm from the host's immune response (Davydov \& Poddubnaya 1988). The demarcation of fibroblasts around the scolex of Monobothrium wageneri, surrounded by a wider periphery of eosinophilic granular cells, adds weight to the likelihood that secretions from the tegumentary glands are responsible for distancing the cellular responses of infected tench. The potential for a parasiteinduced protective mechanism may in part explain the clustered attachment of M. wageneri, allowing tapeworms to establish where intestine integrity has already been breached and host defences compromised. The active discharge of large quantities of secretory products from the scoleces of longestablished tapeworms suggests that this remains an active process for the duration of infection.

The pathological changes caused by the attachment of Monobothrium wageneri exceed those described for all other intestinal tapeworms recorded from British and, possibly, European freshwater fish. This includes, among others, the caryophyllidean cestodes Khawia sinensis (Jara \& Szerow 1981, Morley \& Hoole 1995), Atractolytocestus huronensis (Mackiewicz et al. 1972, Molnár et al. 2003), Cyathocephalus truncatus (Pallas, 1781) (Dezfuli et al. 2000), and C. laticeps (Karanis \& Taraschewski 1993). The damage caused by $M$. wageneri is also more severe than that caused by the attachment of Bothriocephalus acheilognathi and Eubothrium crassum. However, comparisons with these bothriocephalidean cestodes are made with caution, as it is the strobila of these parasites rather than the scolex that may evoke the greatest pathological damage (Smyth 1969, Scott \& Grizzle 1979, Bosi et al. 2005).

Tapeworms are rarely the cause of mortality in wild fish populations (Williams 1965, Rees 1967, Ferguson 1989, Williams \& Jones 1994, Dezfuli et al. 2008) and may exist in high numbers in apparently healthy hosts (Hayunga 1979a). To date, no losses or clinical disease problems have been recorded in tench, suggesting these fish tolerate Monobothrium wageneri infection. However, there is growing awareness that tapeworms can adversely affect host fitness, organ function, growth, condition, behaviour, reproduction, tolerance to environmental stressors and susceptibility to other diseases (Mackiewicz et al. 1972, Granath \& Esch 1983, Hoffmann et al. 1986, Schäperclaus et al. 1991, Dick \& Choudhury 1995, Barber et al. 2000, Hoole et al. 2001, Bosi et al. 2005, Borucinska 2008). These infections can be particularly problematic in juvenile fish (Williams 1965, Körting 1975), although the effects of parasitism can be difficult to identify and evaluate in natural water bodies (Feist \& Longshaw 2008). Although further studies are required to assess the importance of $M$. wageneri to infected tench populations, current observations suggests that this parasite is an undesirable addition to native aquatic environments, with the potential for considerable intestinal damage in parasitized tench.

Acknowledgements. The authors thank the Environment Agency for assistance with obtaining samples of fish for examination. Particular thanks to Linton Brown, Stirling University, for technical help with transmission electron microscopy. The authors are also indebted to Céline Levron and Martina Tesařová, Institute of Parasitology, Czech Republic. Also thanks to Willie Yeomans, Clyde River Foundation, and David Gibson, Natural History Museum, London, for providing information on historic records of Monobothrium wageneri in England. T.S. acknowledges the financial support of the Grant Agency of the Czech Republic (project No. 524/08/0885) and the Institute of Parasitology (projects nos. LC 522 \& Z60220518).

\section{LITERATURE CITED}

Andrews C, Chubb JC, Coles T, Dersley A (1981) The occurrence of Bothriocephalus acheilognathi Yamaguti, 1934 (B. gowkongensis) (Cestoda: Pseudophyllidea) in the British Isles. J Fish Dis 4:89-93

Barber I, Hoare D, Krause J (2000) Effects of parasites on fish behaviour: a review and evolutionary perspective. Rev Fish Biol Fish 10:131-165

Borucinska JD (2008) Diseases caused by Cestoda. In: Eiras JC, Segner H, Wahli T, Kapoor BG (eds) Fish diseases. Science Publishers, Enfield, NH, p 977-1024

Bosi G, Shinn AP, Giari L, Simoni E, Pironi F, Dezfuli BS (2005) Changes in the neuromodulators of the diffuse endocrine system of the alimentary canal of farmed rainbow trout Oncorhynchus mykiss (Walbaum), naturally infected with Eubothrium crassum (Cestoda). J Fish Dis 28:703-711

Caira JN, Littlewood DTJ (2001) Worms, Platyhelminthes. In: Levin S (ed) Encyclopedia of biodiversity, Vol 5. Academic Press, San Diego, CA, p 205-251

Chakravarty R, Tandon V (1989) Caryophylliasis in the catfish, Clarias batrachus L.: some histopathological observations. Proc Ind Acad Sci 98:127-132

Chervy L (2009) Unified terminology for cestode microtriches: a proposal from the International Workshops on Cestode Systematics in 2002-2008. Folia Parasitol 56: 199-230

Chubb JC, Pool DW, Veltkamp CJ (1987) A key to the species of cestodes (tapeworms) parasitic in British and Irish freshwater fishes. J Fish Biol 31:517-545 
Davydov VG, Poddubnaya LG (1988) Functional morphology of frontal and uterine glands in cestodes of the order Caryophyllidea. Parazitologiya 22:449-457 (in Russian)

Dezfuli BS, Arrighi S, Domeneghini C, Bosi G (2000) Immunohistochemical detection of neuromodulators in the intestine of Salmo trutta L. naturally infected with Cyathocephalus truncatus Pallas (Cestoda). J Fish Dis 23: 265-273

> Dezfuli BS, Lui A, Boldrini P, Pironi F, Giari L (2008) The inflammatory response of fish to helminth parasites. Parasite 15:426-433

Dick TA, Choudhury A (1995) Cestoidea (Phylum Platyhelminthes) In: Woo PTK (ed) Fish diseases and disorders, Vol 1. Protozoan and metazoan infections. CAB International, Wallingford, p 391-414

Dubinina MN (1987) Class tapeworms - Cestoda Rudolphi, 1808. In: Bauer ON (ed) Key to the parasites of the freshwater fish fauna of the USSR, Vol 3. Parasitic Metazoa. Opredelitelil po Faune SSSR 149. Leningrad Nauka, Leningrad, p 5-76 (in Russian)

Environment Agency (2004) Our nations' fisheries - the migratory and freshwater fisheries of England and Wales, a snapshot. Environmental Agency, Bristol

Feist SW, Longshaw M (2008) Histopathology of fish parasite infections - importance for populations. J Fish Biol 73:2143-2160

Ferguson HW (1989) Systemic pathology of fish: a text and atlas of comparative tissue responses in diseases of teleosts. Iowa State University Press, Ames, IA

Garo KV (2000) Mode of attachment, histopathology and ultrastructural studies of two cestode species infecting the intestine of the electric catfish, Malapterurus electricus. J Egypt Ger Soc Zool 33D:117-131

Gibson DI (1993) Monobothrium wageneri: another imported tapeworm established in wild British freshwater fishes? J Fish Biol 43:281-285

Gozlan RE, St. Hilaire S, Feist SW, Martin P, Kent ML (2005) Disease threat to European fish. Nature 435:1046

Granath WO, Esch GW (1983) Survivorship and parasiteinduced host mortality among mosquitofish in a predator-free, North Carolina cooling reservoir. Am Midl Nat 110:314-323

Hamada SF, El-Naggar MM (2003) Surface topography, mode of attachment and histopathology of Monobothrioides chalmersius (Cestoidea: Caryophyllidea) from Clarius gariepinus in Egypt. Egypt J Zool 40:185-201

Hayunga EG (1979a) Observations on the intestinal pathology caused by three caryophyllid tapeworms of the white sucker Catostomus commersoni Lacépède. J Fish Dis 2:239-248

Hayunga EG (1979b) The structure and function of the scolex glands of three caryophyllidean tapeworms. Proc Helminthol Soc Wash 46:171-179

Hayunga EG (1991) Morphological adaptations of intestinal helminths. J Parasitol 77:865-873

Hoffman GL (1999) Parasites of North American freshwater fishes, 2nd edn. Cornell University Press, Ithaca, NY

> Hoole D, Nisan H (1994) Ultrastructural studies on intestinal response of carp, Cyprinus carpio L., to the pseudophyllidean tapeworm, Bothriocephalus acheilognathi Yamaguti, 1934. J Fish Dis 17:623-629

Hoole D, Bucke D, Burgess P, Wellby I (2001) Diseases of carp and other cyprinid fishes. Blackwell, London

> Ibraheem MH, Mackiewicz JS (2006) Scolex development, morphology and mode of attachment of Wenyonia virilis
Woodland, 1923 (Cestoidea, Caryophyllidea). Acta Parasitol 51:51-58

Janiszewska J (1954) Caryophyllaeidae europejskie ze szczegolnym uwzglednieniem Polski. Prace Wroclawskiego Towarzystwa Naukowego Ser B 66:1-73

Jara Z, Szerow D (1981) Histopathological changes and localization of the cestode Khawia sinensis in the intestine of carp (Cyprinus carpio). Wiad Parazytol 27:695-703

Jones MK (1998) Structure and diversity of cestode epithelia. Int J Parasitol 28:913-923

Karanis P, Taraschewski H (1993) Host parasite interface of Caryophyllaeus laticeps (Eucestoda: Caryophyllidae) in three species of fish. J Fish Dis 16:371-379

Kennedy CR (1983) General ecology. In: Arme C, Pappas PW (eds) Biology of the Eucestoda, Vol 1. Academic Press, London, p 27-80

Kennedy CR (1994) The ecology of introductions. In: Pike AW, Lewis JW (eds) Parasitic diseases of fish. Samara Publishing, Dyfed, p 189-208

Kirk RS (2003) The impact of Anguillicola crassus on European eels. Fish Manag Ecol 10:385-394

Körting W (1975) Larval development of Bothriocephalus sp. (Cestoda: Pseudophyllidea) from carp (Cyprinus carpio) in Germany. J Fish Biol 7:727-733

Kozicka J (1959) Parasites of fishes of Druzno Lake. Acta Parasitol Pol 7:1-72

Kulakovskaya OP (1961) On the fauna of the Caryophyllaeidae (Cestoda, Pseudophyllidea) of the USSR. Parazitol Sb 20:339-354 (in Russian)

Kuperman BI (1988) Functional morphology of lower cestodes. Ontogenetic and evolutionary aspects. Nauka, Leningrad (in Russian)

> Kuperman BI, Davydov VC (1982) The fine structure of frontal glands in adult cestodes. Int $\mathrm{J}$ Parasitol 12: 285-293

> Mackiewicz JS (1963) Monobothrium hunteri sp. n. (Cestodea: Caryophyllaeidae) from Catostomus commersoni (Lacépède) (Pisces: Catostomidae) in North America. J Parasitol 49:723-730

> Mackiewicz JS (1968) Two new caryophyllaeid cestodes from the spotted sucker, Minytrema melanops (Raf.) (Catostomidae). J Parasitol 54:808-813

Mackiewicz JS (1972) Parasitological review, Caryophyllidea (Cestoidea). Exp Parasitol 31:417-512

> Mackiewicz JS, McCrae R (1962) Hunterella nodulosa gen. n. sp. n. (Cestoidea: Caryophyllaeidae) from Catostomus commersoni (Lacépède) (Pisces: Catostomidae) in North America. J Parasitol 48:798-806

Mackiewicz JS, Cosgrove GE, Gude WD (1972) Relationship of pathology to scolex morphology among caryophyllid cestodes. Z Parasitenkd 39:233-246

Majoros G, Csaba G, Molnár K (2003) Occurrence of Atractolytocestus huronensis Anthony, 1958 (Cestoda: Caryophyllaeidae), in Hungarian pond-farmed common carp. Bull Eur Assoc Fish Pathol 23:167-175

> Molnár K (2005) Histopathological changes caused by the metacestodes of Neogryporhynchus cheilancristrotus (Wedl, 1855) in the gut of the gibel carp, Carassius gibelio. Acta Vet Hung 53:45-52

Molnár K, Majoros G, Csaba G, Szekely C (2003) Pathology of Atractolytocestus huronensis Anthony, 1958 (Cestoda: Caryophyllaeidae) in Hungarian pond-farmed common carp. Acta Parasitol 48:222-228

Morley NJ, Hoole D (1995) Ultrastructure studies on the host-parasite interface between Khawia sinensis (Ces- 
toda: Caryophyllidea) and carp Cyprinus carpio. Dis Aquat Org 23:93-99

Nybelin O (1922) Anatomische-systematische Studien über Pseudophyllidean. Goteb K Vetensk Vitter Hets-Samh Handl 26:1-228

Oros M, Hanzelová V, Scholz T (2009) Tapeworm Khawia sinensis: review of the introduction and subsequent decline of a pathogen of carp, Cyprinus carpio. Vet Parasitol 164:217-222

Poddubnaya LG, Scholz T, Levron C, Kuchta R, Gibson DI (2007) Frontal glands in the pseudoscolex of Paraechinophallus japonicus (Yamaguti, 1934) (Cestoda, Bothriocephalidea, Echinophallidae). Acta Parasitol 52: 325-334

Protasova EN, Kuperman BI, Roitman VA, Poddubnaya LG (1990) The caryophyllidean fauna of the USSR. Nauka, Moscow (in Russian)

Rees G (1967) Pathogenesis of adult cestodes. Helminthol Abs 36:1-36

Richards KS, Arme C (1981) The ultrastructure of the scolexneck syncytium, neck cells and frontal cells of Caryophyllaeus laticeps (Caryophyllidea: Cestoda). Parasitology 83:477-487

Rothman AN (1963) Electron microscope studies of tapeworms: the surface structures of Hymenolepis diminuta (Rudolphi, 1819) Blanchard, 1892. Trans Am Microsc Soc 82:22-30

Schäperclaus W, Kulow H, Schreckenbach K (eds) (1991) Fish diseases, 5th edn. Oxion Press, New Delhi

Scholz T (1987) First record of the cestode Monobothrium

Editorial responsibility: Stephen Feist, Weymouth, UK wageneri Nybelin, 1922 (Caryophyllidea) in Czechoslovakia. Folia Parasitol (Praha) 34:128-130

Scholz T, Paggi L, Di Cave D, Orecchia P (1992) On some cestodes parasitising freshwater fish in Italy. Parassitologia 34:167-178

Scott AL, Grizzle JM (1979) Pathology of cyprinid fishes caused by Bothriocephalus gowkongensis Yeh, 1955. J Fish Dis 2:69-73

> Scott AL, Grizzle JM (1979) Pathology of cyprinid fishes caused by Bothriocephalus gowkongensis Yeh, 1955. J Fish Dis 2:69-73

Sircar M, Sinha DP (1980) Histopathology of Lytocestus indicus infection in the fish Clarias batrachus. Ind J Anim Res 14:53-56

Smyth JD (1969) The physiology of cestodes. Oliver \& Boyd, Edinburgh

> Sures B, Taraschewski H, Rokicki J (1997) Lead and cadmium content of two cestodes Monobothrium wageneri, and Bothriocephalus scorpii, and their fish hosts. Parasitol Res 83:618-623

Whittington ID, Cribb BW (2001) Adhesive secretions in the platyhelminths. Adv Parasitol 48:101-224

Williams HH (1965) Helminth diseases of fish. Helminthol Abs 36:261-295

Williams EH (1974) Two new species of Monobothrium (Cestoda: Carophyllaeidae) from catostomid fishes of the southeastern United States. Trans Am Fish Soc 103: 610-615

Williams H, Jones A (1994) Parasitic worms of fishes. Taylor \& Francis, London

Submitted: February 7, 2011; Accepted: August 25, 2011

Proofs received from author(s): November 28, 2011 